\title{
The Illyrian mesic forests of the Villány Mts: phytosociology and conservation importance
}

\author{
László ERDös ${ }^{1 *}$, Zoltán BÁTORI ${ }^{2}$, Csaba TöLGYeSI ${ }^{2} \&$ Balázs KeveY $^{3}$ \\ ${ }^{1}$ Institute of Ecology and Botany, MTA Centre for Ecological Research, H-2163 Vácrátót, Alkotmány utca 2-4., Hungary; \\ e-mail: erdos.laszlo@okologia.mta.hu \\ ${ }^{2}$ Department of Ecology, University of Szeged, H-6726 Szeged, Közép fasor 52., Hungary \\ ${ }^{3}$ Department of Ecology, University of Pécs, H-7624 Pécs, Ifjúság útja 6., Hungary
}

\begin{abstract}
Situated at the interface of Central European and Illyrian vegetation, the mesic forests of southwestern Hungary occupy a special position. Despite their importance in vegetation science and conservation, a comprehensive study of the Illyrian mesic forests of the Villány Mts, the southernmost mountain region in Hungary, has not been provided yet. In this study 60 phytocoenological relevés were prepared in the beech, oak-hornbeam, ravine and scree forests of the Villány Mts. To compare the individual associations, we performed a PCoA-ordination, calculated the per plot species number and the per plot protected species number, computed the percentage constancy values of the protected species, identified significant diagnostic species, and prepared the spectra of the coenological preference groups. We used relative ecological indicator values to assess habitat conditions. The PCoA-ordination, the coenological preference group spectra, and to a certain extent the ecological indicator values suggested that the different mesic forests of the Villány Mts show certain similarities. This is probably due to the fact that beech forests and ravine forests are confined to small and atypical stands by the suboptimal environmental conditions. Nonetheless, the number of diagnostic species and the constancy values of protected plants indicated that significant differences do exist between the four associations, the scree forest being the most distinct. We conclude that oak-hornbeam forests and scree forests of the Villány Mts have a regional conservation importance, while the beech and ravine forests are locally important, enhancing the structural, floristical and habitat diversity of the Villány Mts.
\end{abstract}

Key words: Fagetalia sylvaticae; Aremonio-Fagion; Fagion illyricum; beech forest; oak-hornbeam forest; ravine forest; scree forest.

\section{Introduction}

Mesic deciduous forests of the order Fagetalia sylvaticae belong to the most widespread vegetation types of Europe (Ellenberg 1988; Dierschke 1997; Dierschke \& Bohn 2004; Mucina et al. 2016). The order contains a high variety of zonal, azonal and intrazonal associations, including beech forests as well as communities with other dominant tree species (Ellenberg 1988; Török et al. 1989; Borhidi et al. 2012). The mesic deciduous forests of the western Balkan Peninsula can be classified into the alliance Aremonio-Fagion (formerly Fagion illyricum), i.e. Illyrian mesic deciduous forests (Borhidi 1963, 1965; Soó 1964; Horvat et al. 1974; Török et al. 1989; Borhidi \& Kevey 1996; Dierschke 1997; Redžić 2007; Marinšek et al. 2013; Mucina et al. 2016; but see Willner 2002), although the location of the border between Aremonio-Fagion and $\mathrm{Fa}$ gion moesiacae is somewhat uncertain.

Associations belonging to the alliance AremonioFagion are typical in the Dinarides and the neigh- boring areas (e.g. Horvat et al. 1974; Dzwonko et al. 1999; Dzwonko \& Loster 2000; Surina 2002; Trinajstić \& Pavletić 2004; Surina \& Rakaj 2007), but they also occur in southern Austria (Zukrigl 1988) and southwestern Hungary (Török et al. 1989; Borhidi et al. 2012). In Hungary, they have a special conservation importance because they host several protected, redlisted and relic species (Kevey 2008). In fact, Illyrian type forests may be regarded as relic communities in Hungary (Borhidi et al. 2012), although this has been debated by Brus (2010), who concluded that Aremonio-Fagion communities may have developed relatively late, during the Holocene. As the floristic composition of several mesic forest types in southwestern Hungary is rather similar, oak-hornbeam forests, scree forests and ravine forests are also included in the alliance Aremonio-Fagion (Borhidi \& Kevey 1996; Kevey 2008; Borhidi et al. 2012).

The Villány Mts form the southernmost mountain region in Hungary; thus, the Illyrian influence is prominent here (Dénes 2000) and affects the Aremonio-

\footnotetext{
* Corresponding author
} 
A

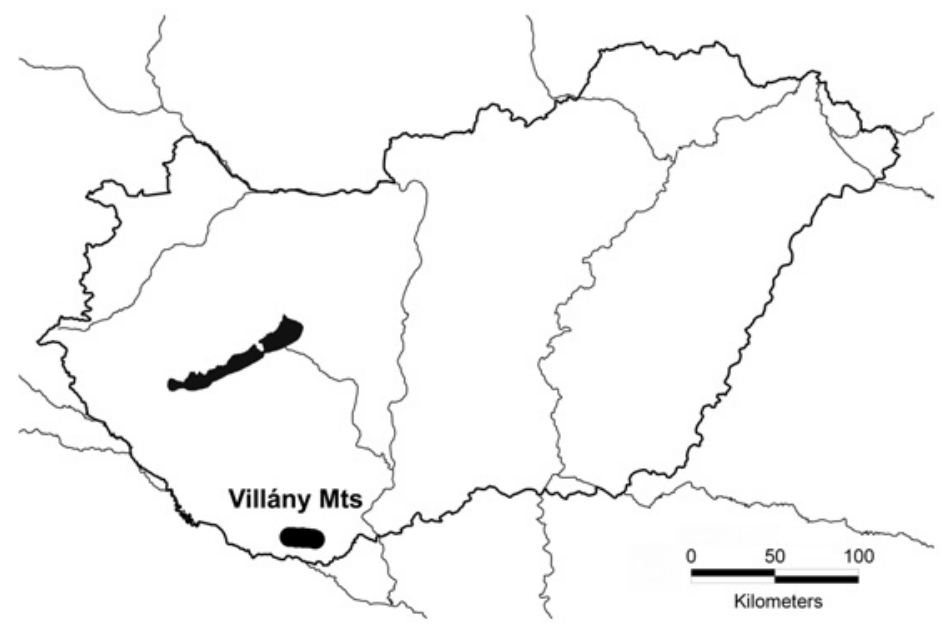

B

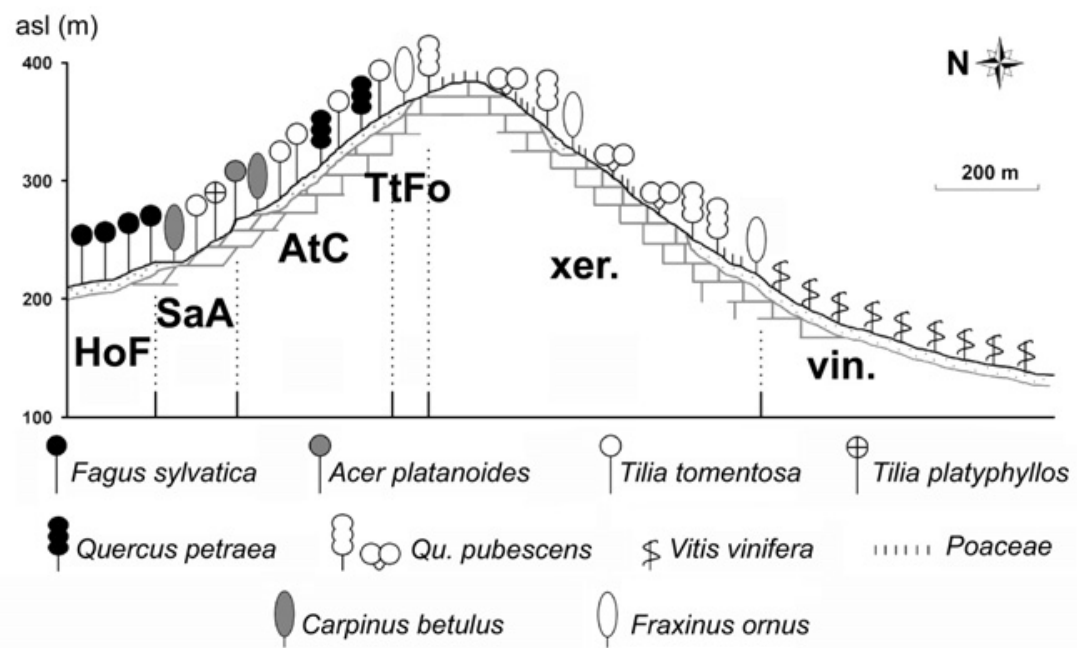

Fig. 1. A - Location of the Villány Mts in southern Hungary; B - Idealized vegetation profile of the Villány Mts. HoF: beech forest, SaA: ravine forest, AtC: oak-hornbeam forest, TtFo: scree forest, xer.: xeric grassland-forest mosaic, vin.: vineyard.

Fagion communities as well (Kevey 2008). In the Villány Mts, there are four associations belonging to the alliance Aremonio-Fagion. The most widespread of them is the oak-hornbeam forest Asperulo taurinaeCarpinetum, which covers considerable areas on the north-facing slopes (Horvát 1968, 1972; Kevey 2016). In contrast, beech forests (Helleboro odori-Fagetum) are restricted to cool and moist habitats, usually near the northern foots of the mountains (Kevey 1986). The ravine forest Scutellario altissimae-Aceretum is represented by only a few small stands in the Villány Mts (Kevey 1984). Stands of the scree forest Tilio tomentosae-Fraxinetum orni occur near the mountain tops and ridges (Erdös et al. 2012).

In spite of their importance in vegetation science and conservation, a comprehensive overview and comparative study of the Aremonio-Fagion forests of the Villány Mts is still lacking. The primary aim of this pa- per is to provide a phytosociological characterization of the Illyrian mesic deciduous forests of the Villány Mts. In addition, by analyzing the floristic distinctness of the communities, as well as their species richness and the number of protected species, we intended to assess the conservation importance of these forests. Our results may be used as a basis for further phytosociological studies and for conservation and forestry decisions.

\section{Material and methods}

\section{Study area}

The Villány Mts are situated in southwestern Hungary (Fig. 1a). This small mountain range consists of limestone and at some places dolomite, both of which are covered by loess on most of the north-facing slopes and near the foots of the mountains (Lovász 1977). The mean annual temperature is $10.5^{\circ} \mathrm{C}$, the mean annual precipitation is $660-680 \mathrm{~mm}$ (Dövényi 2010). The natural vegetation of the south-facing 
slopes as well as the upper sections of the north-facing slopes is composed of xeric forest and grassland communities (Erdős et al. 2012), which have been replaced by vineyards in large areas. Due to the low altitudes, mesic forests are confined to the north-facing slopes (Fig. 1b); unfortunately, a considerable proportion has been turned into Robinia and Pinus plantations, while near-natural stands have survived primarily in the central and eastern parts of the Villány Mts.

The Villány Mts belong to the phytogeographical region Praeillyricum within the province Pannonicum (Borhidi \& Sánta 1999), displaying a strong transitional character towards the Illyricum.

\section{Field works}

Earlier studies have suggested that $1600 \mathrm{~m}^{2}$ plots be used in mesic forests of the region, instead of the usual plot size of $400 \mathrm{~m}^{2}$ (Kevey 2008). However, taking into account the small size of beech, ravine and scree forest stands in the Villány Mts, we decided to use an intermediate plot size. Thus, in the present study we prepared our coenological relevés in $900 \mathrm{~m}^{2}$ plots. The number of relevés per association was as follows: beech forest: 20 plots, oak-hornbeam forest: 20 plots, ravine forest: 5 plots, scree-forests: 15 plots (the latter two associations are very rare in the study area). The percentage cover of all vascular plant species was estimated within each plot in March-April (spring aspect) and JulyAugust (summer aspect), according to the Braun-Blanquet scale. Spring and summer records were combined prior to data analyses. Some structural characteristics (height and cover of all vegetation layers) and habitat parameters (elevation, exposition, inclination, soil type) were also recorded.

\section{Data analysis}

Principal Coordinates Analysis (PCoA) with the BaroniUrbani-Buser index was performed to study the floristic similarity of the relevés. The analysis was based on presenceabsence data and was performed in R ( R Development Core Team 2008).

We compared the per plot species number and per plot protected species number among the four communities. Data normality was tested using the Shapiro-Wilk test. The Kruskal-Wallis test and subsequent Mann-Whitney pairwise comparisons were performed to test the differences between communities. Statistical analyses were carried out with SPSS 17.0 (SPSS Inc.).

Diagnostic species, i.e. species that are typical of one of the communities while absent or rare in the other three communities, were identified using the phi-coefficient, the most appropriate indicator of fidelity (i.e. species concentration in one of the studied communities) (Tichý \& Chytrý 2006). The phi-coefficient compares observed species frequencies within a given community with frequencies that would be expected if the species was randomly distributed. Significant $(P<0.05)$ diagnostic species were identified with the software JUICE 7.0.45 (Tichý 2002). Only species with phi values $>0.300$ were considered during our work. If a species was diagnostic for two habitats, only the habitat with the higher phi value was taken into consideration.

To complement the approach of diagnostic species, we calculated the percentage constancy values of all protected species in the four communities. We gave additional information on the conservation status of these species, based on the Red list of the vascular flora of Hungary (Király et al. 2007).

For all communities, we calculated the spectra of coenological preference groups. The following twelve groups were used: (1) general deciduous forest species (Quercetea robori-petraeae, Querco-Fagetea), (2) mesic forest species (Fagetalia), (3) plants strongly related to beech forests (Fagion sylvaticae), (4) plants strongly related to oakhornbeam forests (Carpinion betuli), (5) species related to ravines and gorges (Aceri-Fagion), (6) species of Illyrian mesic forests (Aremonio-Fagion, Primulo-Fagenion), (7) xeric forest species (Quercetalia pubescentis-petraeae, OrnoOstryon, Aceri tatarico-Quercion), (8) species of scrubs ( $S a-$ licion albae, Prunetalia spinosae, Pruno-Rubion ulmifolii), (9) species typical of dry grasslands (Festuco-Brometea, Festucetalia valesiacae, Festucion valesiacae), (10) species of weed communities (Chenopodietea, Secalietea, Artemisietalia, Arction lappae, Calystegietalia, Glechometalia), (11) others (Phragmitetalia, Hypno-Polypodietalia, Epilobietea angustifolii, Atropetalia, Atropion, Alno-Ulmion), and (12) indifferent species. For the categorization, the system of Borhidi (1995) was used. To test whether the four communities differed in the spectra of coenological preference groups, we conducted a chi-square test with SPSS 17.0 (SPSS Inc.).

Relative ecological indicator values were applied to assess site conditions of the communities studied. Numerous earlier studies have shown that ecological indicator values provide a reliable estimate of abiotic environmental factors (i.e. estimated values correlate well with instrumentally measured values) (e.g. Barczi et al. 1997; Schaffers \& Sýkora 2000; Tölgyesi et al. 2014). Despite some critics (Möller 1992), calculating mean indicator values has a firm theoretical basis and has performed well in several analyses (ter Braak \& Gremmen 1987; Diekmann 2003; Otýpková 2009). We used the indicator values for temperature $(\mathrm{T})$, soil moisture $(\mathrm{W})$, soil nutrient content $(\mathrm{N})$ and light availability $(\mathrm{L})$ (Ellenberg et al. 1992; Borhidi 1995). Frequency-weighted mean indicator values were computed for all relevés. After testing normality with the Shapiro-Wilk test, the four associations were compared with One-way ANOVA and subsequent Tukey HSD tests or Kruskal-Wallis test and subsequent Mann-Whitney comparisons, depending on data distribution.

Nomenclature follows Király (2009) for plant species and Borhidi et al. (2012) for plant associations.

\section{Results}

Habitat conditions and structural characteristics

In this section we describe basic habitat conditions and structural characteristics of the four associations under study.

The beech forest Helleboro odori-Fagetum occurs on north-, west- or east-facing slopes between 150 and $300 \mathrm{~m}$ a.s.l. The bedrock is almost exclusively limestone, sometimes dolomite, both of which are covered by loess. The association always grows on brown forest soil. The upper canopy is tall $(25-30 \mathrm{~m})$ and dense ( $85-95 \%$ cover). The dominant species is Fagus sylvatica, but Carpinus betulus, Quercus petraea and Tilia tomentosa are also widespread. The lower canopy is $12-18 \mathrm{~m}$ tall and its cover is $5-25 \%$. Its most important components are Fagus sylvatica and Carpinus betulus, but Fraxinus ornus and Tilia tomentosa are also frequent and reach considerable cover values occasionally. The height range of the shrub layer is $0.5-3 \mathrm{~m}$; its cover varies between 2 and $40 \%$ and the most important constituents are Cornus sanguinea, Rubus fru- 


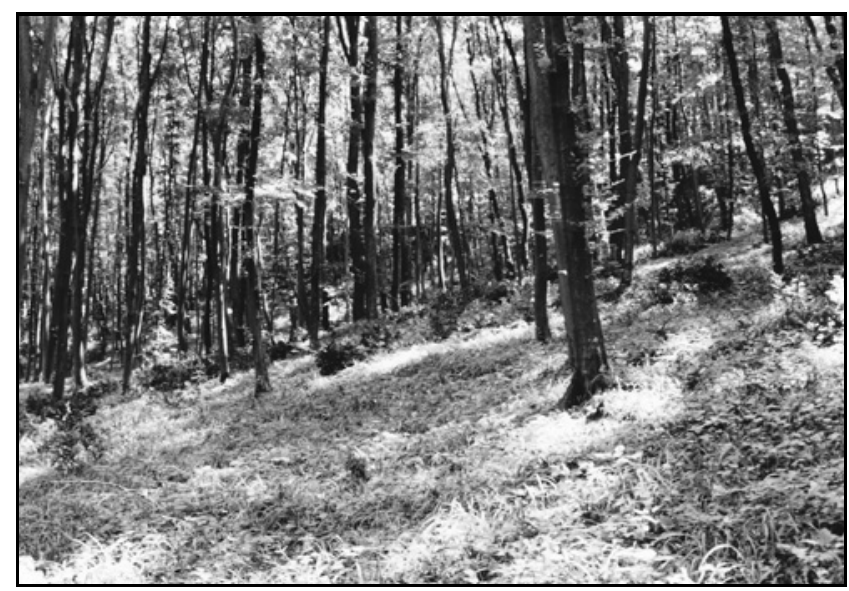

Fig. 2. Oak-hornbeam forest (Asperulo taurinae-Carpinetum) is the most widespread mesic forest in the Villány Mts, where the high abundance of Tilia tomentosa and Ruscus aculeatus is typical.

ticosus agg., Ruscus aculeatus, Staphylea pinnata, and tree saplings. The herb layer is $1-50 \mathrm{~cm}$ high; its cover values vary extremely, ranging from almost nudum (2$3 \%$ ) to $100 \%$. The most frequent and abundant species include Cardamine bulbifera, Carex pilosa, Corydalis cava,Galeobdolon montanum, and Galium odoratum.

The oak-hornbeam forest Asperulo taurinae-Carpinetum (Fig. 2) favors north-facing slopes between 120 and $350 \mathrm{~m}$ a.s.l. The bedrock is limestone or dolomite with a loess cover, although some rocks may be near or on the surface. The soil is brown forest soil. The upper canopy (height: 20-30 m, cover: 75-90\%) consists of Quercus petraea, Tilia tomentosa, Carpinus betulus, to a lesser degree Cerasus avium and Quercus cerris. The lower canopy (12-20 m, 5-40\%) is dominated by Carpinus betulus and Tilia tomentosa, but
Acer campestre and Ulmus glabra are also typical. The shrub layer is $0.5-4 \mathrm{~m}$ in height and its cover is $5-60 \%$. Its most abundant and frequent species are Ruscus aculeatus, Staphylea pinnata, and the young tree individuals, most importantly Acer campestre and Tilia tomentosa. Dominant species of the herb layer $(2-50 \mathrm{~cm}$, 55-100\%) are Allium ursinum, Carex pilosa, Corydalis cava, Galium odoratum, Mercurialis perennis, and $R a-$ nunculus ficaria.

The ravine forest Scutellario altissimae-Aceretum is restricted to the ravines of north-facing slopes in altitudes between 170 and $220 \mathrm{~m}$ a.s.l. It always occurs in very small stands. The bedrock is limestone or dolomite, the soil is rendzina. The heigth of the upper canopy is $15-25 \mathrm{~m}$, its cover is $70-85 \%$. The dominant species are Carpinus betulus, Tilia tomentosa and Ulmus glabra. Other typical trees are Acer platanoides and Tilia platyphyllos. The lower canopy is usually 10$12 \mathrm{~m}$ high and its cover is $20-40 \%$. It is formed by the same species as the upper canopy. The most important constituents of the shrub layer (1-2.5 m, 10-50\%) are Sambucus nigra, Staphylea pinnata, and tree saplings. The herb layer $(2-50 \mathrm{~cm}, 15-70 \%)$ is dominated by Cardamine bulbifera, Galeobdolon montanum and several ferns (primarily Asplenium scolopendrium, Dryopteris filix-mas, Polystichum aculeatum, and P. setiferum).

The scree forest Tilio tomentosae-Fraxinetum orni can be found exclusively on rather steep north-facing slopes between $250-380 \mathrm{~m}$ a.s.l. It forms long and narrow stripes near the ridges. The bedrock is limestone or dolomite, the soil is rendzina. The upper canopy is 15-20 m high, its cover is $60-80 \%$. The main species are Tilia tomentosa, T. platyphyllos, and Fraxinus ornus. The lower canopy $(10-12 \mathrm{~m}, 20-50 \%)$ is formed primarily by Fraxinus ornus and Tilia tomentosa. The most frequent and abundant plants of the shrub layer

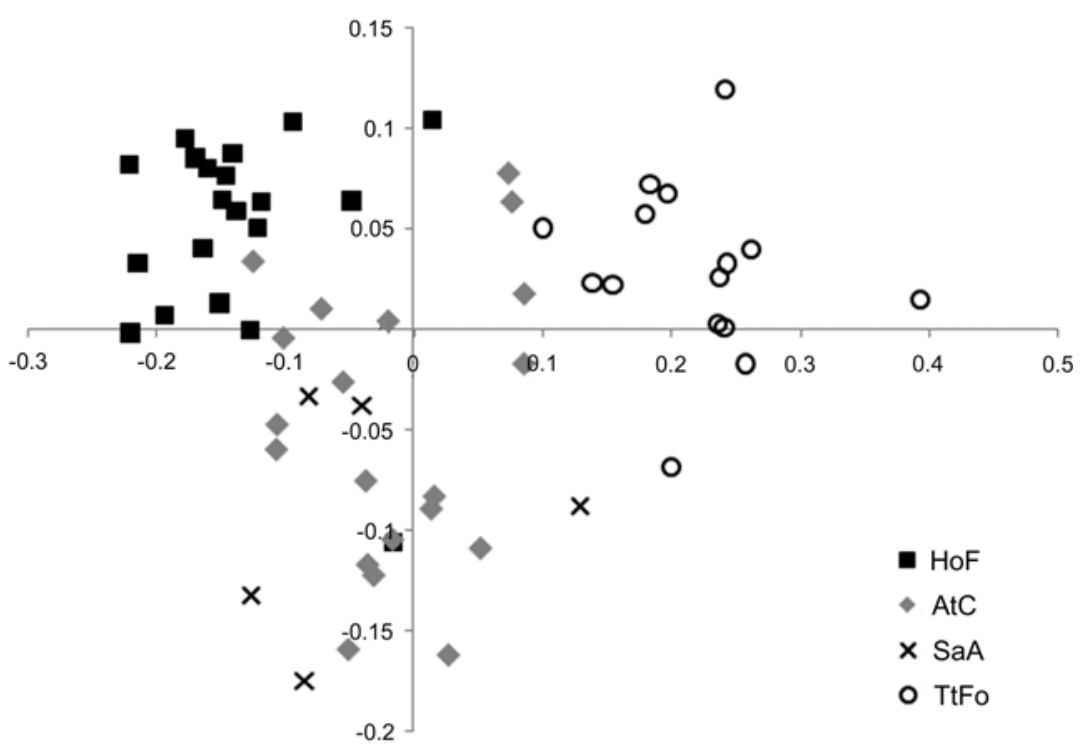

Fig. 3. Ordination scattergram of the 60 coenological relevés (principal coordinate analysis, Baroni-Urbani-Buser index). HoF: beech forest, AtC: oak-hornbeam forest, SaA: ravine forest, TtFo: scree forest. Percentage variances explained by the first and the second axes are 20.79 and $6.87 \%$, respectively. 
A

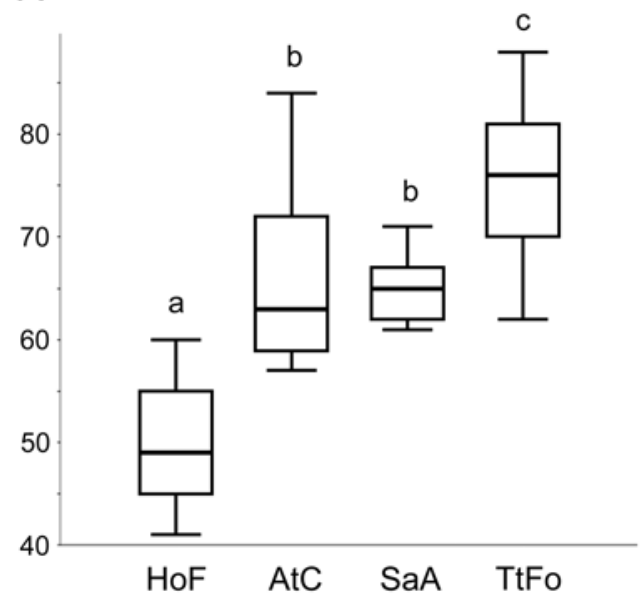

B

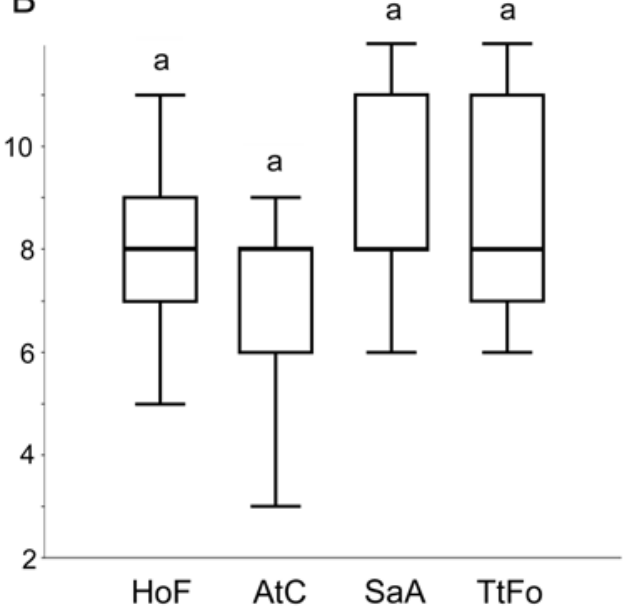

Fig. 4. Per plot species number (A) and per plot protected species number (B) of the four associatons studied. HoF: beech forest, AtC: oak-hornbeam forest, SaA: ravine forest, TtFo: scree forest. Boxes not sharing a letter are significantly $(P<0.01)$ different.

Table 1. Significant $(P<0.05)$ diagnostic species of the beech forest $(\mathrm{HoF})$, the oak-hornbeam forest (AtC), the ravine forest $(\mathrm{SaA})$, and the scree forest (TtFo). Species with phi-values not exceeding 0.3 were not taken into account.

\begin{tabular}{lllll}
\hline & $\mathrm{HoF}$ & AtC & $\mathrm{SaA}$ & $\mathrm{TtFo}$ \\
\hline Convallaria majalis & 0.462 & & & \\
Neottia nidus-avis & 0.461 & & & \\
Ajuga reptans & 0.406 & & & \\
Ruscus hypoglossum & 0.393 & & & \\
Lathyrus venetus & 0.385 & & & \\
Platanthera bifolia & 0.342 & & \\
Vitis sylvestris & 0.342 & & \\
Fagus sylvatica & 0.322 & & \\
Carex digitata & 0.318 & & \\
Carex sylvatica & 0.318 & & \\
Melittis melissophyllum & 0.303 & & \\
\hline
\end{tabular}

\begin{tabular}{ll}
\hline Quercus robur & 0.434 \\
Stachys sylvatica & 0.422 \\
Rumex sanguineus & 0.392 \\
Stellaria holostea & 0.381 \\
Moehringia trinervia & 0.361 \\
Stellaria media & 0.356 \\
Veronica montana & 0.342 \\
Allium ursinum & 0.335 \\
Carex pilosa & 0.330 \\
Quercus petraea & 0.323 \\
Scrophularia nodosa & 0.323
\end{tabular}

\begin{tabular}{lll}
\hline Polystichum aculeatum & 0.829 & \\
Asplenium scolopendrium & 0.728 & \\
Polystichum setiferum & 0.687 & \\
Galeopsis speciosa & 0.547 & \\
Aegopodium podagraria & 0.525 & \\
Athyrium filix-femina & 0.525 & \\
Dryopteris filix-mas & 0.513 & \\
Milium effusum & 0.509 & \\
Galium aparine & 0.505 & \\
Actaea spicata & 0.480 & \\
Tilia platyphyllos & 0.427 & \\
& & \\
\hline \multirow{2}{*}{ Hylotelephium telephium } & & \multirow{2}{*}{1.000} \\
Rosa canina agg. & & 0.833 \\
Corydalis solida & & 0.758 \\
Quercus pubescens & & 0.728 \\
Clinopodium vulgare & & 0.697 \\
Glechoma hirsuta & & 0.660 \\
Carex pairaei & & 0.629 \\
& &
\end{tabular}

Table 1. (continued)

\begin{tabular}{|c|c|c|c|c|}
\hline & $\mathrm{HoF}$ & AtC & $\mathrm{SaA}$ & TtFo \\
\hline Viola odorata & & & & 0.619 \\
\hline Fallopia dumetorum & & & & 0.583 \\
\hline Scutellaria altissima & & & & 0.580 \\
\hline Aconitum anthora & & & & 0.577 \\
\hline Campanula persicifolia & & & & 0.577 \\
\hline Digitalis grandiflora & & & & 0.577 \\
\hline Euonymus verrucosus & & & & 0.577 \\
\hline Vincetoxicum hirundinaria & & & & 0.577 \\
\hline Fragaria vesca & & & & 0.547 \\
\hline Arum orientale & & & & 0.538 \\
\hline Gagea minima & & & & 0.538 \\
\hline Bromus ramosus agg. & & & & 0.531 \\
\hline Asplenium trichomanes & & & & 0.527 \\
\hline Doronicum orientale & & & & 0.525 \\
\hline Cystopteris fragilis & & & & 0.522 \\
\hline Iris variegata & & & & 0.522 \\
\hline Alliaria petiolata & & & & 0.509 \\
\hline Cornus mas & & & & 0.509 \\
\hline Lamium maculatum & & & & 0.489 \\
\hline Crataegus monogyna & & & & 0.471 \\
\hline Muscari botryoides & & & & 0.466 \\
\hline Prunus spinosa & & & & 0.466 \\
\hline Dictamnus albus & & & & 0.463 \\
\hline Polypodium vulgare & & & & 0.463 \\
\hline Lapsana communis & & & & 0.448 \\
\hline Veronica hederifolia & & & & 0.424 \\
\hline Chelidonium majus & & & & 0.419 \\
\hline Dactylis polygama & & & & 0.404 \\
\hline Lactuca quercina & & & & 0.404 \\
\hline Asplenium javorkeanum & & & & 0.397 \\
\hline Polygonatum odoratum & & & & 0.397 \\
\hline Silene nemoralis & & & & 0.397 \\
\hline Silene noctiflora & & & & 0.397 \\
\hline Viburnum lantana & & & & 0.397 \\
\hline Sambucus nigra & & & & 0.389 \\
\hline Geum urbanum & & & & 0.378 \\
\hline Ligustrum vulgare & & & & 0.377 \\
\hline Ornithogalum sphaerocarpum & & & & 0.376 \\
\hline Scilla vindobonensis & & & & 0.376 \\
\hline Chaerophyllum temulum & & & & 0.361 \\
\hline Anthriscus cerefolium & & & & 0.350 \\
\hline Torilis japonica & & & & 0.350 \\
\hline Buglossoides purpurocaerulea & & & & 0.342 \\
\hline Clematis vitalba & & & & 0.332 \\
\hline Galanthus nivalis & & & & 0.323 \\
\hline Fraxinus ornus & & & & 0.322 \\
\hline Geranium robertianum & & & & 0.322 \\
\hline
\end{tabular}


(0.5-3.5 m, 40-70\%) are Cornus mas, Crataegus monogyna, and Ruscus aculeatus. Dominant plants of the herb layer (2-40 cm, 25-80\%) are Corydalis cava, C. solida, Geranium robertianum, Glechoma hirsuta, and Ranunculus ficaria.

Species composition and conservation importance In the 60 plots we found a total of 225 species.

The relevés from the beech forest, the oakhornbeam forest and the scree forest formed three clearly distinguishable but not especially distinct groups in the ordination scattergram (Fig. 3). In contrast, ravine forest plots were scattered among the oakhornbeam forest plots.

The Kruskal-Wallis test indicated a significant difference between the per plot species number of the associations $(H=44.39, P<0.001)$. According to the post-hoc comparisons, scree forests were significantly more species-rich than any of the other communities under study, while the beech forest community proved to be the least species rich, the oak-hornbeam forest and the ravine forest being intermediate (Fig. 4a).

Considering only the number of protected species per plot, there were no signifcant differences among the four associations according to the Kruskal-Wallis test ( $H=3.005, P=0.3731$ ), although ravine forest and scree-forest plots seemed to possess a higher number of protected species (Fig. 4b).

We managed to identify several significant $(P<$ $0.05)$ diagnostic species for all the four communities (Table 1). The beech forest, the oak-horbeam forest and the ravine forest had 11 diagnostic species each, while the scree forest possessed 54 diagnostic species. Several of the diagnostic species of the beech forest prefer shady and rather moist habitats (e.g. Carex digitata, Neottia nidus-avis, Ruscus hypoglossum), while the species associated with the oak-hornbeam forest tend to have somewhat higher light and lower moisture requirements (e.g. Carex pilosa, Stellaria holostea). Almost half of the diagnostic species of the ravine forest were ferns (e.g. Asplenium scolopendrium, Polystichum aculeatum). The scree forest had numerous diagnostic species that are nitrofrequent (Chelidonium majus, Lamium maculatum), ferns (Asplenium trichomanes, Cystopteris fragilis), or usually occur on warm and dry mountain tops and southern slopes (e.g. Aconitum anthora, Dictamnus albus).

We encountered 32 protected species during the study (Table 2). One of them, Digitalis ferruginea is endangered and rare throughout Hungary, ten species are listed in the Hungarian red list, and one species, Ruscus aculeatus is listed in Annex V of the EU Habitats Directive. Among the protected species, some were present with high constancies in all four communities (e.g. Helleborus odorus). A considerable amount of protected species was restricted to one (e.g. Asplenium scolopendrium, Vitis sylvestris), two (e.g. Aconitum vulparia, Scilla vindobonensis) or three (e.g. Cephalanthera damasonium, Hepatica nobilis) forest communities. Finally, some species occurred in all communities, but their constancy was high only in one of them (e.g. Polystichum setiferum).

The four communities under study did not differ significantly with respect to coenological preference groups $\left(\mathrm{chi}^{2}=33.851, P=0.4251\right)$ (Fig. 5). All associations were dominated by general species of deciduous forests and (with the exception of the scree forest) Fagetalia species. Although there were only minor differences in most cases, it is worth noting that the scree forest seemed to be rather different in certain respects: it had by far the lowest proportion of Fagetalia and Fagion sylvaticae species and a very high proportion of xeric forest species.

Mean indicator values proved to be significantly different among the four associations for temperature (ANOVA $F=7.713, P<0.001$ ), moisture (ANOVA $F=32.800, P<0.001$ ), soil nutrient content (ANOVA $\mathrm{F}=12.880, P<0.001$ ), and light availability (KruskalWallis $H=39.440, P<0.001)$. The beech forest seemed to be moist, nutrient-poor and rather shady, while the oak-hornbeam forest had higher soil nutrient content and higher light availability values (Fig. 6). The ravine forest could be characterized by cool temperature, high soil nutrient content and low light availability. Scree forests were indicated as warm, dry and sunny habitats.

\section{Discussion}

Although some publications about the syntaxonomical position of the mesic forests of southwestern Hungary are available (e.g. Borhidi \& Kevey 1996; Kevey 2008; Borhidi et al. 2012), an overview of the Fagetalia forests of the Villány Mts has not been prepared yet. The aim of this study was to fill this gap.

Due to the low altitudes, almost the whole territory of the Villány Mts belongs to the turkey oak-sessile oak zone (Borhidi et al. 2012). Although the cool and humid microclimate of north-facing slopes (Lehmann 1995) enables the existence of Fagetalia forests, communities with a higher moisture and lower temperature requirement (beech forest and ravine forest) form only small and somewhat atypical stands. The suboptimal conditions are reflected in the minor differences for some ecological indicator values, e.g. the similarity of temperature values for the beech and oak-hornbeam forests (Fig. 6a), or the similar moisture values of the beech, oak-hornbeam and ravine forests (Fig. 6b). This probably contributes to the coenological similarity of the studied communities, which is apparent in the ordination scattergram (Fig. 3) and the distribution of the coenological preference groups (Fig. 5). Also, Kevey (1984, 1986) recognized that beech and ravine forest stands of the Villány Mts resemble oak-hornbeam forests in certain aspects. Similar results have been reported from the nearby Mecsek Mts based on both coarse-scale (Bátori et al. 2009) and fine-scale (Bátori et al. 2014) studies: mesic forest types were rather similar to one another with respect to species composition and abiotic parameters.

Nevertheless, the number of diagnostic species sug- 
Table 2. Conservations status and percentage constancy values of the protected species in the beech forest (HoF), the oak-hornbeam forest (AtC), the ravine forest ( $\mathrm{SaA})$ and the scree forest ( $\mathrm{TtFo})$. Red-list categories: NT: near-threatened, VUL: vulnerable, END: endangered. Other categories: ST: strictly protected, HD Ann.: listed in Annex V. of the EU Habitats Directive.

\begin{tabular}{|c|c|c|c|c|c|}
\hline & \multirow{2}{*}{ Cons. status } & \multicolumn{4}{|c|}{ Constancy \% } \\
\hline & & $\mathrm{HoF}$ & AtC & $\mathrm{SaA}$ & TtFo \\
\hline Aconitum anthora & NT & 0 & 0 & 0 & 40 \\
\hline Aconitum vulparia & & 5 & 10 & 0 & 0 \\
\hline Asperula taurina & NT & 35 & 75 & 40 & 73 \\
\hline Asplenium javorkeanum & NT & 0 & 0 & 0 & 20 \\
\hline Asplenium scolopendrium & NT & 0 & 0 & 60 & 0 \\
\hline Cephalanthera damasonium & & 20 & 5 & 0 & 7 \\
\hline Cephalanthera longifolia & & 10 & 5 & 0 & 7 \\
\hline Dictamnus albus & & 0 & 0 & 0 & 27 \\
\hline Digitalis ferruginea & ST, END & 0 & 0 & 0 & 7 \\
\hline Doronicum orientale & VUL & 0 & 5 & 0 & 40 \\
\hline Epipactis helleborine & & 30 & 5 & 20 & 7 \\
\hline Galanthus nivalis & & 45 & 65 & 40 & 87 \\
\hline Helleborus odorus & & 100 & 100 & 100 & 100 \\
\hline Hepatica nobilis & & 20 & 25 & 40 & 0 \\
\hline Iris variegata & & 0 & 0 & 0 & 33 \\
\hline Lathyrus venetus & & 75 & 40 & 40 & 13 \\
\hline Lilium martagon & & 60 & 75 & 80 & 60 \\
\hline Lonicera caprifolium & & 60 & 60 & 80 & 40 \\
\hline Lunaria annua & & 0 & 0 & 20 & 7 \\
\hline Muscari botryoides & NT & 0 & 5 & 0 & 33 \\
\hline Neottia nidus-avis & & 45 & 5 & 0 & 13 \\
\hline Orchis purpurea & & 0 & 0 & 0 & 7 \\
\hline Ornithogalum sphaerocarpum & NT & 0 & 15 & 0 & 33 \\
\hline Platanthera bifolia & & 15 & 0 & 0 & 0 \\
\hline Polystichum aculeatum & & 5 & 0 & 80 & 0 \\
\hline Polystichum setiferum & NT & 10 & 5 & 80 & 13 \\
\hline Primula vulgaris & & 0 & 20 & 20 & 7 \\
\hline Ruscus aculeatus & HD Ann. & 100 & 100 & 80 & 100 \\
\hline Ruscus hypoglossum & & 70 & 25 & 40 & 13 \\
\hline Scilla vindobonensis & & 0 & 15 & 0 & 33 \\
\hline Tamus communis & & 85 & 75 & 80 & 67 \\
\hline Vitis sylvestris & END & 15 & 0 & 0 & 0 \\
\hline
\end{tabular}

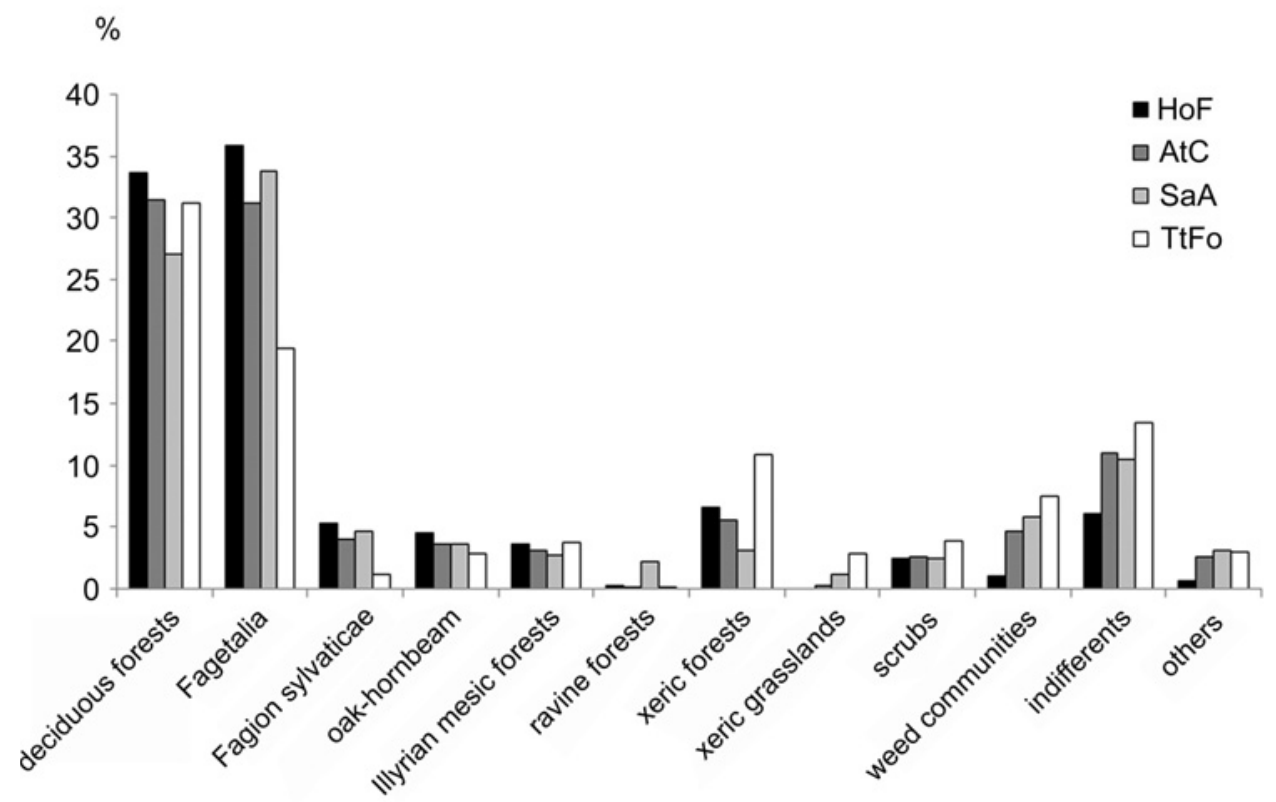

Fig. 5. Spectra of the coenological preference groups in the four communities. HoF: beech forest, AtC: oak-hornbeam forest, SaA: ravine forest, TtFo: scree forest.

gests that there are important differences among the four communities (Table 1). In addition, several pro- tected species tend to be restricted to or concentrated in certain community types, while they are absent or rare 
A

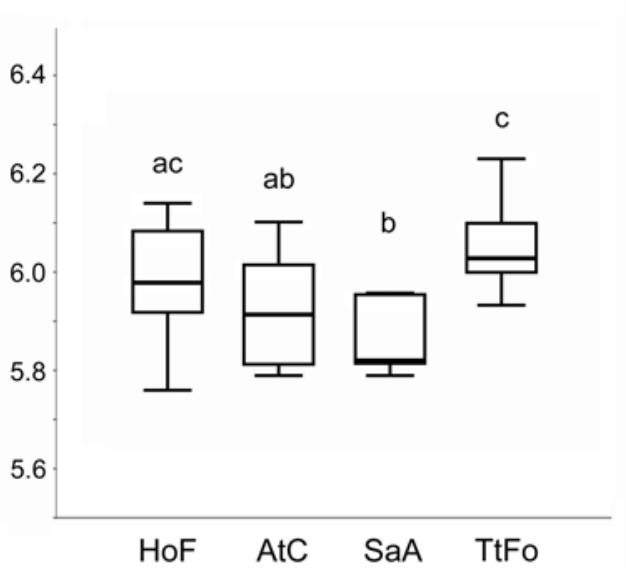

C

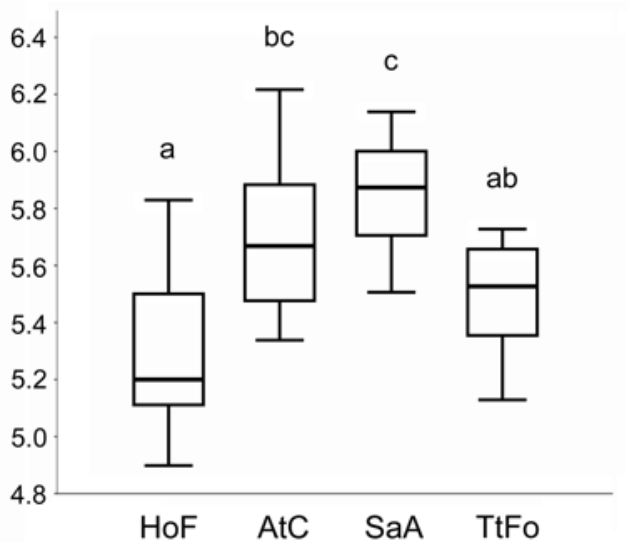

B
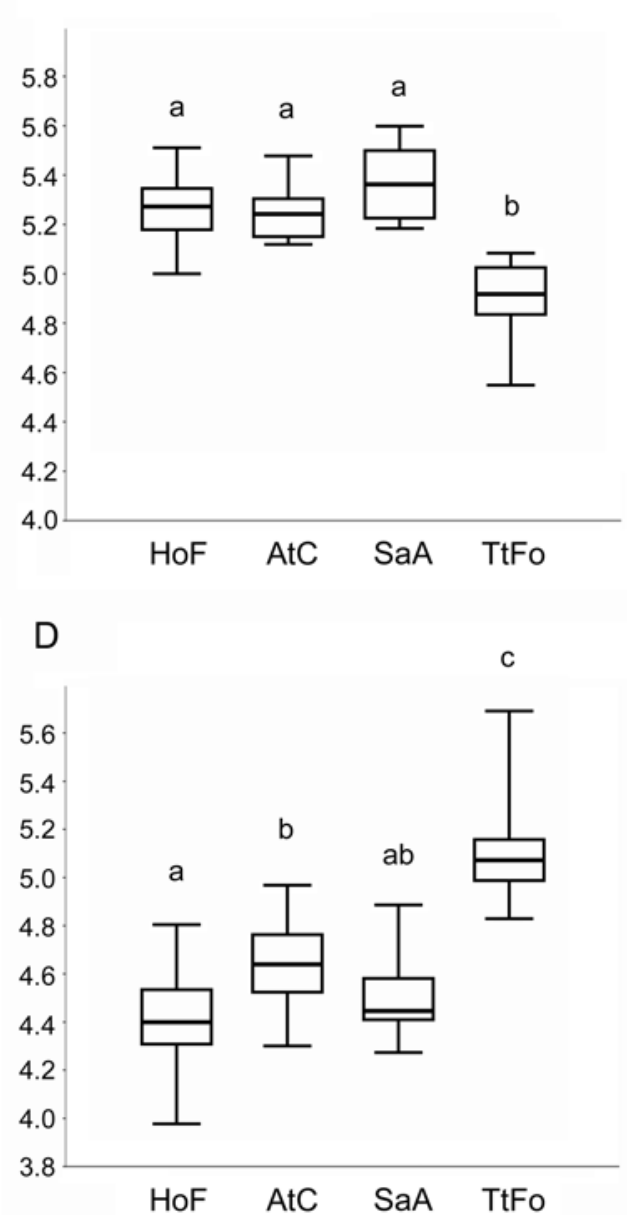

Fig. 6. Ecological indicator values for temperature (A), moisture (B), soil nutrient content (C), and light availability (D) in the four associations under study. HoF: beech forest, AtC: oak-hornbeam forest, SaA: ravine forest, TtFo: scree forest. Boxes not sharing a letter are significantly $(P<0.05)$ different.

elsewhere (Table 2). Some of these species deserve special attention, because they are rare in the Villány Mts (e.g. Asplenium scolopendrium) or in the whole country (e.g. Digitalis ferruginea) (cf. Dénes 2000; Kevey 2004).

The spatial arrangement of the plant communities on the north-facing slopes represents a clear vegetation inversion (Fig. 1b). Beech forests usually occupy the lowest areas, near the foots of the mountains. Oak-hornbeam forests can typically be found at somewhat higher elevations. Near the ridges or mountain tops, besides scree forests, termophilous forests such as top-forests (Aconito anthorae-Fraxinetum orni) or turkey oak-sessile oak forest (Potentillo micranthaeQuercetum dalechampii) can occasionally be found (Erdös et al. 2015). This inversion has already been noted earlier, although only for the upper sections of the north-facing slopes (Erdős et al. 2012). There are no measurements concerning temperature and moisture gradients in the Villány Mts, but it can be assumed that climatic inversion plays a major role in shaping the above patterns. The extreme arid conditions of the southern slopes presumably influence not only the ridges and plateaus, but also the upper areas of the north-facing slopes, especially if southerly winds are taken into account. In contrast, low elevation sites of the north-facing slopes may be influenced by the cool and humid valleys and by the effects of the streamlets running near the mountain foots.

The oak-hornbeam forest Asperulo taurinae-Carpinetum is the most widespread mesic forest in the study area. It is a unique community in Hungary, and some of its most valuable stands can be found in the Villány Mts. The beech forest Helleboro odori-Fagetum and the ravine forest Scutellario altissimae-Aceretum are especially vulnerable in the Villány Mts, due to the small size of the stands and the suboptimal climatic parameters. Since they have much larger and more typical stands elsewhere in southwestern Hungary (e.g. Horvát 1972; Kevey 1993), their importance is mainly local: they increase the structural, floristical and habitat diversity of the Villány Mts. The scree forest Tilio tomentosae-Fraxinetum orni proved to be the most species-rich among the four communities (Fig. 4a). This may partly be due to its spatial position (Fig. 1b) and microclimate. It is warmer and dryer than the other three mesic forest types and several dry forest species can coexist here with mesic plants. This transitional character is similar to the top-forest Aconito anthoraeFraxinetum orni, the species pool of which consists of both mesic and xeric plants (Kevey \& Borhidi 1998; 
Erdős et al. 2015). Due to its rarity and diversity, the scree forest Tilio tomentosae-Fraxinetum orni undoubtedly has regional conservation significance in the Pannonian biogeographical area.

We conclude that all four plant communities covered by this analysis have high conservation values. Similarly, Borhidi \& Sánta (1999) suggested that these forests should be protected. At present, the main threatening factors are incorrect forestry practices and the spread of invasive species (most importantly Robinia pseudoacacia) (Borhidi \& Sánta 1999; Haraszthy 2014). As we see it, clear-cutting should be avoided even in areas that are not under legal protection currently. Also, non-native plantations should be replaced by native ones, which, in the long run, could result in near-natural forests.

As already noted in the Introduction, the syntaxonomic position of the Illyrian mesic deciduous forest associations is somewhat uncertain. More specifically, the border between Aremonio-Fagion and Fagion moesicae is subject to scientific debates, which has consequences for the South-Hungarian mesic forests as well. For example, Dzwonko \& Loster (2000), based on a multivariate analysis, proposed that the Serbian Helleboro odoriFagetum forests should be classified into the alliance Aremonio-Fagion. In this case, the line between the two alliances would be more to the east. In contrast, the numerical analyses of Marinšek et al. (2013) suggested that the North-Croatian and Serbian Fagus forests on lowlands and hills belong to the alliance Fagion moesiacae, placing the border more to the west. As the Hungarian forest associations discussed in the present paper are near the northern periphery of the Balcanic forests, an additional question arises: where to place the border between Fagion sylvaticae and AremonioFagion. Bohn \& Gollub (2007) defined a distinct category for the beech forests situated in the contact zone of the southeastern Alps, the Illyrian region and the Carpathian Basin. As shown by the study of Török et al. (1989), South-Hungarian Fagetalia forests are closely related to the Croatian and North-Serbian communities. Although the syntaxonomic position of the four mesic forest associations of the Villány Mts was not the topic of this paper, we think that the syntaxonomic system of Kevey (2008) and Borhidi et al. (2012) may be considered the best option for the region, classifying the mesic deciduous forests of the Villány Mts into the alliance Aremonio-Fagion.

\section{References}

Barczi A., Penksza K., Czinkota I. \& Néráth M. 1997. A study of connection between certain phytoecological indicators and soil characteristics in the case of the Tihany Peninsula. Acta Bot. Hung. 40: 1-14.

Bátori Z., Csiky J., Erdős L., Morschhauser T., Török P. \& Körmöczi L. 2009. Vegetation of the dolines in Mecsek Mountains (South Hungary) in relation to the local plant communities. Acta Carsologica 38: 237-252.

Bátori Z., Farkas T, Erdős L., Tölgyesi Cs., Körmöczi L. \& Vojtkó A. 2014. A comparison of the vegetation of forested and non- forested solution dolines in Hungary: a preliminary study. Biologia 69: 1339-1348.

Bohn U. \& Gollub G. 2007. Buchenwälder als natürliche Vegetation in Europa. Nat. Landsch. 82: 391-397.

Borhidi A. 1963. Die Zönologie des Verbandes Fagion illyricum. I. Allgemeiner Teil. Acta Bot. Hung. 9: 259-297.

Borhidi A. 1965. Die Zönologie des Verbandes Fagion illyricum. II. Systematischer Teil. Acta Bot. Hung. 11: 53-102.

Borhidi A. 1995. Social behaviour types, the naturalness and relative ecological indicator values of the higher plants in the Hungarian flora. Acta Bot. Hung. 39: 97-181.

Borhidi A. \& Kevey B. 1996. An annotated checklist of the Hungarian plant communities II. The forest vegetation, pp. 95138. In: Borhidi A. (ed.), Critical revision of the Hungarian plant communities, Janus Pannonius University, Pécs.

Borhidi A., Kevey B. \& Lendvai G. 2012. Plant communities of Hungary. Akadémiai Kiadó, Budapest, 544 pp.

Borhidi A. \& Sánta A. (eds) 1999. Vörös könyv Magyarország növénytársulásairól I. Természetbúvár Alapítvány Kiadó, Budapest, $362 \mathrm{pp}$.

Brus R. 2010. Growing evidence for the existence of glacial refugia of European beech (Fagus sylvatica L.) in the south-eastern Alps and north-western Dinaric Alps. Period. Biol. 112: 239246.

Dénes A. 2000. A Villányi-hegység flóra- és vegetációkutatásának története, eredményeinek összefoglalása, különös tekintettel a védett és ritka fajok előfordulására. Dunántúli Dolg. Természettudományi Sorozat 10: 47-77.

Diekmann M. 2003. Species indicator values as an important tool in applied plant ecology: a review. Basic Appl. Ecol. 4: 493506.

Dierschke H. 1997. Syntaxomomical survey of European beech forests: Some general conclusions. Ann. Bot. (Rome) 55: 1726.

Dierschke H. \& Bohn U. 2004. Eutraphente Rotbuchenwälder in Europa. Tuexenia 24: 19-56.

Dövényi Z. (ed.) 2010. Magyarország kistájainak katasztere. MTA Földrajztudományi Kutatóintézet, Budapest, 876 pp.

Dzwonko Z. \& Loster S. 2000. Syntaxonomy and phytogeographical differentiation of the Fagus woods in the Southwest Balkan Peninsula. J. Veg. Sci. 11: 667-678.

Dzwonko Z., Loster S., Dubiel E. \& Drenkovski R. 1999. Syntaxonomic analysis of beechwoods in Macedonia (former Republic of Yugoslavia). Phytocoenologia 29: 153-175.

Ellenberg H. 1988. Vegetation ecology of Central Europe. Fourth edition. Cambridge University Press, Cambridge, 731 pp.

Ellenberg H., Weber H.E., Düll R., Wirth V., Werner W. \& Paulißen D. 1992. Zeigerwerte von Pflanzen in Mitteleuropa. Scr. Geobot. 18: 1-248.

Erdős L., Dénes A., Tolnay D., Magnes M., Bátori Z., Tölgyesi Cs. \& Kevey B. 2015. Phytosociology and nature conservation value of thermophilous oak forests in a South Hungarian karst area. Austrian J. For. Sci. 132: 145-168.

Erdős L., Méri Á., Bátori Z., Gallé R. \& Körmöczi L. 2012. North-south facing vegetation gradients in the Villány Mts: a case study on the population and the community level. Pak. J. Bot. 44: 927-932.

Haraszthy L. (ed) 2014. Natura 2000 fajok és élőhelyek Magyarországon. Pro Vértes Közalapítvány, Csákvár, 955 pp.

Horvát A.O. 1968. Die Hainbuchen-Eichenwälder der MecsekGegend in Südungarn. Feddes Rep. 77: 163-176.

Horvát A.O. 1972. Die Vegetation des Mecsekgebirges und seiner Umgebung. Akadémiai Kiadó, Budapest, 376 pp.

Horvat I., Glavač V. \& Ellenberg H. 1974. Vegetation Südosteuropas. Gustav Fischer, Stuttgart, 768 pp.

Kevey B. 1984. Fragmentális szurdokerdők a Villányi-hegységb̄en. Janus Pannonius Múz. Évk. 29: 23-28.

Kevey B. 1986. A Villányi-hegység bükkösei. Janus Pannonius Múz. Évk. 30-31: 7-9.

Kevey B. 1993. A Keleti-Mecsek szurdokerdei (ScutellarioAceretum). Folia Comloensis 5: 29-54.

Kevey B. 2004. Dél-Dunántúl fokozottan védett növényei. Kitaibelia 9: 67-83.

Kevey B. 2008. Magyarország erdőtársulásai. Tilia 14: 1-488. 
Kevey B. 2016. A Villányi-hegység gyertyános-tölgyesei. Acta Nat. Pannon. 10: 21-46.

Kevey B. \& Borhidi A. 1998. Top-forest (Aconito anthoraeFraxinetum orni), a special ecotonal case in the phytosociological system (Mecsek Mts., South Hungary). Acta Bot. Hung. 41: 27-121.

Király G. (ed.) 2007. Vörös Lista: A magyarországi edényes flóra veszélyeztetett fajai. Saját kiadás, Sopron, 73 pp.

Király G. (ed.) 2009. Új magyar füvészkönyv. Aggteleki Nemzeti Park Igazgatóság, Jósvafő, 616 pp.

Lehmann A. 1995. Földrajzi tanulmányutak a Mecseken és környékén. Janus Pannonius Tudományegyetem, Pécs, 147 pp.

Lovász Gy. 1977. Geomorfológiai körzetek, pp. 43-93. In: Lovász Gy. (ed.), Baranya megye természeti földrajza, Baranya Megyei Levéltár, Pécs.

Marinšek A., Šilc U. \& Čarni A. 2013. Geographical and ecological differentiation of Fagus forest vegetation in SE Europe. Appl. Veg. Sci. 16: 131-147.

Möller H. 1992. Zur Verwendung des Medians bei Zeigerwertberechnungen nach Ellenberg. Tuexenia 12: 25-28.

Mucina L., Bültmann H., Dierßen K., Theurillat J.-P., Raus T. Čarni A., Šumberová K., Willner W., Dengler J., Gavilán García R., Chytrý M., Hájek M., Di Pietro R., Iakushenko D., Pallas J., Daniëls F.J.A., Bergmeier E., Santos Guerra A., Ermakov N., Valachovič M., Schaminée J.H.J., Lysenko T., Didukh Y.P, Pignatti S., Rodwell J.S., Capelo J., Weber H.E., Solomeshch A., Dimopoulos P., Aguiar C., Hennekens S.M. \& Tichý L. 2016. Vegetation of Europe: hierarchical floristic classification system of vascular plant, bryophyte, lichen, and algal communities. Appl. Veg. Sci. 19 (Suppl. 1): 3-264.

Otýpková Z. 2009. The influence of sample plot size on evaluations with Ellenberg indicator values. Biologia 64: 1123-1128.

R Development Core Team. 2008. R: A language and environment for statistical computing. - R Foundation for Statistical Computing, Vienna, Austria. URL: http://R-project.org.

Redžić S. 2007. Syntaxonomic diversity as an indicator of ecological diversity - case study Vranica Mts in the Central Bosnia. Biologia 62: 173-184.
Schaffers A.P. \& Sýkora K.V. 2000. Reliability of Ellenberg indicator values for moisture, nitrogen and soil reaction: a comparison with field measurements. J. Veg. Sci. 11: 225-244.

Soó R. 1964. Die regionale Fagion-Verbände und Gesellschaften Südosteuropas. Studia Biol. Hung. 4: 1-104.

Surina B. 2002. Phytogeographical differentiation in the Dinaric fir-beech forest (Omphalodo-Fagetum s. lat.) of the western part of the Illyrian floral province. Acta Bot. Croat. 61: 145178.

Surina B. \& Rakaj M. 2007. Subalpine beech forest with hairy alpenrose (Polysticho lonchitis-Fagetum rhododendretosum hirsuti subass. nova) on Mt. Snežnik (Li burnian karst, Dinaric Mts). Hacquetia 6: 195-208.

ter Braak C.F.J. \& Gremmen N.J.M. 1987. Ecological amplitudes of plant species and the internal consistency of Ellenberg's indicator values for moisture. Vegetatio 69: 79-87.

Tölgyesi Cs., Bátori Z. \& Erdős L. 2014. Using statistical tests on relative ecological indicators to compare vegetation units - different approaches and weighting methods. Ecol. Indic. 36: $441-446$.

Török K., Podani J. \& Borhidi A. 1989. Numerical revision of the Fagion illyricum alliance. Vegetatio 81: 169-180.

Trinajstić I. \& Pavletić Z. 2004. The association HacquetioFagetum Košisr 1962 (Aremonio-Fagion) in Croatia. Hacquetia 3: $29-42$.

Tichý L. 2002. JUICE, software for vegetation classification. J. Veg. Sci. 13: 451-453.

Tichý L. \& Chytrý M. 2006. Statistical determination of diagnostic species for site groups of unequal size. J. Veg. Sci. 17: 809-818.

Willner W. 2002. Syntaxonomische Revision der südmitteleuropäischen Buchenwälder. Phytocoenologia 32: 337-453.

Zukrigl K. 1988. Die montanen Buchenwälder der österreichischen Südalpen (Karawanken und Karnische Alpen). Sauteria 4: 11-16.

Received November 29, 2016

Accepted February 2, 2017 